\title{
Front Matter: Volume 9457
}

, "Front Matter: Volume 9457," Proc. SPIE 9457, Biometric and Surveillance Technology for Human and Activity Identification XII, 945701 (2 June 2015); doi: $10.1117 / 12.2184327$

SPIE. Event: SPIE Defense + Security, 2015, Baltimore, MD, United States 


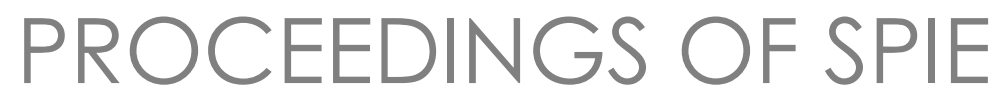

\section{Biometric and Surveillance Technology for Human and Activity Identification XII}

loannis A. Kakadiaris

Ajay Kumar

Walter J. Scheirer

Editors

22 April 2015

Baltimore, Maryland, United States

Sponsored and Published by

SPIE 
The papers included in this volume were part of the technical conference cited on the cover and title page. Papers were selected and subject to review by the editors and conference program committee. Some conference presentations may not be available for publication. The papers published in these proceedings reflect the work and thoughts of the authors and are published herein as submitted. The publisher is not responsible for the validity of the information or for any outcomes resulting from reliance thereon.

Please use the following format to cite material from this book:

Author(s), "Title of Paper," in Biometric and Surveillance Technology for Human and Activity Identification XII, edited by loannis A. Kakadiaris, Ajay Kumar, Walter J. Scheirer, Proceedings of SPIE Vol. 9457 (SPIE, Bellingham, WA, 2015) Article CID Number.

ISSN: 0277-786X

ISBN: 9781628415735

Published by

SPIE

P.O. Box 10, Bellingham, Washington 98227-0010 USA

Telephone +1 3606763290 (Pacific Time) · Fax +1 3606471445

SPIE.org

Copyright @ 2015, Society of Photo-Optical Instrumentation Engineers.

Copying of material in this book for internal or personal use, or for the internal or personal use of specific clients, beyond the fair use provisions granted by the U.S. Copyright Law is authorized by SPIE subject to payment of copying fees. The Transactional Reporting Service base fee for this volume is $\$ 18.00$ per article (or portion thereof), which should be paid directly to the Copyright Clearance Center (CCC), 222 Rosewood Drive, Danvers, MA 01923. Payment may also be made electronically through CCC Online at copyright.com. Other copying for republication, resale, advertising or promotion, or any form of systematic or multiple reproduction of any material in this book is prohibited except with permission in writing from the publisher. The CCC fee code is 0277-786X/15/\$18.00.

Printed in the United States of America.

Publication of record for individual papers is online in the SPIE Digital Library.

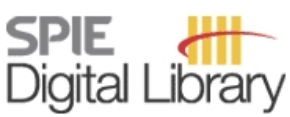

SPIEDigitalLibrary.org

Paper Numbering: Proceedings of SPIE follow an e-First publication model, with papers published first online and then in print. Papers are published as they are submitted and meet publication criteria. A unique citation identifier (CID) number is assigned to each article at the time of the first publication. Utilization of CIDs allows articles to be fully citable as soon as they are published online, and connects the same identifier to all online, print, and electronic versions of the publication. SPIE uses a six-digit CID article numbering system in which:

- The first four digits correspond to the SPIE volume number.

- The last two digits indicate publication order within the volume using a Base 36 numbering

system employing both numerals and letters. These two-number sets start with 00, 01, 02, 03, 04, $05,06,07,08,09,0 A, 0 B \ldots$. 0Z, followed by 10-1Z, 20-2Z, etc.

The CID Number appears on each page of the manuscript. The complete citation is used on the first page, and an abbreviated version on subsequent pages. 


\title{
Contents
}

\author{
$\checkmark \quad$ Authors \\ vii Conference Committee
}

\section{BIOMETRIC PRIVACY}

945702 Implementation and optimization of a biometric cryptosystem using iris recognition [9457-1]

$945703 \quad$ Fingerprint + Iris = IrisPrint [9457-2]

945704 Identifying Bitcoin users by transaction behavior [9457-3]

\section{HUMAN BEHAVIOR}

945706 Human task performance baseline: results from a cross-band facial identification perception study [9457-6]

IRIS AND EYE MOVEMENT

945708 A gallery approach for off-angle iris recognition [9457-8]

9457 OA An indexing method for color iris images [9457-10]

LIGHTNING TALK SESSION

9457 OB Deep learning and face recognition: the state of the art [9457-1 1]

9457 OC Computational cameras for moving iris recognition [9457-12]

9457 OD Privacy protection schemes for fingerprint recognition systems [9457-13]

9457 OE Anti-spoofing for display and print attacks on palmprint verification systems [9457-14]

9457 OF Biometrics IRB best practices and data protection [9457-16]

NOVEL MODALITIES AND SURVEILLANCE

9457 OG Open-set speaker identification with diverse-duration speech data [9457-17] 
Proc. of SPIE Vol. $9457945701-4$

Downloaded From: https://www.spiedigitallibrary.org/conference-proceedings-of-spie on 26 Apr 2023 Terms of Use: https://www.spiedigitallibrary.org/terms-of-use 


\section{Authors}

Numbers in the index correspond to the last two digits of the six-digit citation identifier (CID) article numbering system used in Proceedings of SPIE. The first four digits reflect the volume number. Base 36 numbering is employed for the last two digits and indicates the order of articles within the volume. Numbers start with 00, 01, 02, 03, 04, 05, 06, 07, 08, 09, 0A, 0B...0Z, followed by 10-1Z, 20-2Z, etc.

Ariyaeeinia, Aladdin, $0 G$

Balaban, Stephen, OB

Bhilare, Shruti, OE

Boehnen, Christopher, 08, OF

Bolme, David, OF

Byrd, Kenneth A., 06

Chaudhari, Narendra, OE

Choi, Hee-Sue, 06

Crihalmeanu, Simona G., OA

Cukic, Bojan, OD

Flynn, Patrick, OF

Garg, Pragalbh, OE

Hertlein, Heinz, OG

Kanhangad, Vivek, $\mathrm{OE}$

Karadaghi, Rawande, OG

Karakaya, Mahmut, 08

Liu, Chen, 02

Marasco, Emanuela, OD

McCloskey, Scott, OC

McGuffey, Charles, 02

Monaco, John V., 04

Othman, Asem, 03

Ross, Arun A., 03, 0A

Schuckers, Stephanie, 02

Singh, Pranjalya, OE

Venkatesha, Sharath, OC

Yoldash, Rashiduddin, 08 
Proc. of SPIE Vol. $9457945701-6$

Downloaded From: https://www.spiedigitallibrary.org/conference-proceedings-of-spie on 26 Apr 2023 Terms of Use: https://www.spiedigitallibrary.org/terms-of-use 


\section{Conference Committee}

Symposium Chair

Nils R. Sandell Jr., Strategic Technology Office, DARPA

(United States)

Symposium Co-chair

David A. Logan, BAE Systems (United States)

Conference Chairs

loannis A. Kakadiaris, University of Houston (United States)

Ajay Kumar, The Hong Kong Polytechnic University (Hong Kong, China)

Walter J. Scheirer, Harvard University (United States)

Conference Program Committee

J. Ross Beveridge, Colorado State University (United States)

Christopher Bensing Boehnen, Oak Ridge National Laboratory (United States)

Terrance E. Boult, University of Colorado at Colorado Springs

(United States)

Thirimachos Bourlai, West Virginia University (United States)

Rama Chellappa, University of Maryland, College Park (United States)

Bernadette Dorizzi, TELECOM \& Management SudParis (France)

Julian Fierrez, Universidad Autónoma de Madrid (Spain)

Brian C. Heflin, University of Colorado at Colorado Springs (United States)

Daniel P. Lopresti, Lehigh University (United States)

Norman Poh, University of Surrey (United Kingdom)

Nalini K. Ratha, IBM Thomas J. Watson Research Center (United States)

Anderson Rocha, Universidade Estadual de Campinas (Brazil)

Arun A. Ross, Michigan State University (United States)

Natalia A. Schmid, West Virginia University (United States)

Stephanie Schuckers, Clarkson University (United States)

William R. Schwartz, UFMG (Brazil)

Shishir Shah, University of Houston (United States)

Kar-Ann Toh, Yonsei University (Korea, Republic of)

Raymond N. J. Veldhuis, Universiteit Twente (Netherlands)

Ruigang Yang, University of Kentucky (United States) 
Session Chairs

1 Biometric Privacy

Walter J. Scheirer, Harvard University (United States)

2 Human Behavior

Ajay Kumar, The Hong Kong Polytechnic University (Hong Kong, China)

3 Keynote Session

Ioannis A. Kakadiaris, University of Houston (United States)

4 Iris and Eye Movement

Walter J. Scheirer, Harvard University (United States)

5 Lightning Talk Session

Ajay Kumar, The Hong Kong Polytechnic University (Hong Kong, China)

6 Novel Modalities and Surveillance

loannis A. Kakadiaris, University of Houston (United States)

7 Emerging Perspectives in Biometrics

Walter J. Scheirer, Harvard University (United States) 